\title{
Establishing Legumes in a Tall Fescue Sward
}

\author{
Doo-Hong Min ${ }^{1}$, Joseph L. Moyer ${ }^{2 *}$ \\ ${ }^{1}$ Department of Agronomy, Kansas State University, Manhattan, KS, USA \\ ${ }^{2}$ Southeast Agricultural Research Center, Kansas State University, Parsons, KS, USA \\ Email: “jmoyer@ksu.edu
}

Received 31 December 2014; accepted 8 February 2015; published 12 February 2015

Copyright (C) 2015 by authors and Scientific Research Publishing Inc.

This work is licensed under the Creative Commons Attribution International License (CC BY). http://creativecommons.org/licenses/by/4.0/

c) (i) Open Access

\section{Abstract}

Tall fescue [Schedonorus arundinaceus (Schreb.) Dumort.] is a common grass species in the eastern half of the USA, but legumes grown with it could provide benefits. Obstacles to legume establishment in fescue pastures include disease, insect damage, and grass competition. Experiments were performed in 2010 and 2011 at Site 1 to test the efficacy of insect control, disease control, and two methods of grass suppression on seedling establishment of three legumes. The highest seedling density of red clover (Trifolium pretense L.) was obtained with glyphosate treatment regardless of pest control and for clipping without pest control. No overall or consistent benefit was found for white clover (Trifolium pretense L.) or trefoil (Lotus corniculatus L.) from seed and foliar insecticides or fungicides, or for grass suppression by either clipping or glyphosate application. Experiments were performed in 2012 and 2013 at Site 2 to test the efficacy of grass suppression by grazing cattle or by clethodim application. Seedling density of red clover was not significantly improved by either treatment, but the density of birdsfoot trefoil was increased by clethodim, and the density of white clover was increased in 2013 by both methods of grass suppression. Overall, red clover was least sensitive to grass competition. Birdsfoot trefoil was better served by the immediate effect of chemical suppression, whereas white clover benefitted most from the lengthier grass suppression provided by grazing.

\section{Keywords}

Red Clover, White (Ladino) Clover, Birdsfoot Trefoil, Herbicide, Grazing

\section{Introduction}

Pastures composed of legumes and grasses benefit from nitrogen $(\mathrm{N})$ transfer from legumes to grasses. Legumes such as alfalfa (Medicago sativa L.) and soybean [Glycine max (L.) Merr.] can provide an annual average of 152 $\mathrm{kg}$ and $84 \mathrm{~kg} \mathrm{~N} \mathrm{ha}{ }^{-1}$, respectively, via symbiotic $\mathrm{N}$ fixation [1]. Pasture legumes can fix 80 to $110 \mathrm{~kg} \cdot \mathrm{ha}^{-1} \cdot \mathrm{yr}^{-1} \mathrm{of}$

${ }^{*}$ Corresponding author. 
symbiotic N for companion grasses [2] [3]. Legumes grown with grasses also provide a more uniform seasonal distribution of forage than pure cool-season grass pastures because legumes such as alfalfa are less likely to go dormant during mid-summer [4].

Tall fescue [Schedonorus arundinaceus (Schreb.) Dumort.] is one of the most common grass species in the humid transition zone between the temperate North and mild South in the eastern half of the USA [5]. It was also one of the most dominant species in complex mixtures with other grasses and legumes at the end of a grazing study in Pennsylvania [6]. Maintaining adequate legumes in tall fescue was related to improved animal performance and farm profitability [7]. Ladino clover (Trifolium repens L.) interseeded into endophyte-infected tall fescue was more profitable than $\mathrm{N}$-fertilized tall fescue alone [8]. In a plot study in southeastern Kansas with multiple legumes, returns from birdsfoot trefoil (Lotus corniculatus L.) were greater than those from alfalfa as well as from red and white clovers [9].

Legume species have differed in their effects on animal performance in fescue pasture. Allen et al. [10] reported that body weight gains of calves grazing stockpiled pastures of alfalfa-tall fescue were greater than those grazing red clover-tall fescue or N-fertilized tall fescue. Ladino clover in endophyte-infected tall fescue also resulted in better average animal gains than red clover or Korean lespedeza [11].

Despite the benefits known to occur from interseeding legumes into tall fescue, procedures have not been developed to the point that managers can incorporate legumes into pastures with any degree of confidence [2]. Approaches to improving legume establishment in tall fescue are numerous and include no-till drilling of legumes into tall fescue pasture [11]; controlling grass competition with herbicides [12], mowing, or grazing [13]; limiting $\mathrm{N}$ fertilization [14]; and planting pastures with different row orientations [15]. Although considerable research has been conducted on legume establishment, little progress has been made to address many of the problems, such as disease, insect damage, heat and/or water stress, and poor seedling vigor [2]. The experiments in this study were undertaken to identify and manage the most limiting factors in the complex interactions among diseases, insects, interplant competition, and the environment.

\section{Materials and Methods}

\subsection{Experiment 1: Pest Control and Grass Suppression}

Legume species were interseeded separately into endophyte-infected tall fescue at the Mound Valley Unit of the Kansas State University Southeast Agricultural Research Center ( $\left.37^{\circ} 11.5^{\prime} \mathrm{N}, 95^{\circ} 27.4^{\prime} \mathrm{W}\right)$. The plot area had been seeded to tall fescue $>2$ years prior to the test, and had been hayed without benefit of fertilization. The soil was a Parsons silt loam (fine, mixed thermic Mollic Albaqualf) with a pH of $6.3,7 \mathrm{mg} \cdot \mathrm{kg}^{-1}$ of available P (Mehlich 3), and $128 \mathrm{mg} \cdot \mathrm{kg}^{-1}$ of exchangeable $\mathrm{K}$ in the upper $15 \mathrm{~cm}$, to which was added $25 \mathrm{~kg} / \mathrm{ha}$ of $\mathrm{P}$ and $28 \mathrm{~kg} / \mathrm{ha}$ of $\mathrm{K}$. Spring temperature and precipitation data for the location in 2010 and 2011 are listed in Table 1.

Species were planted with a no-till plot seeder (6 rows with $25-\mathrm{cm}$ spacings, at $\sim 5 \mathrm{~mm}$ depth) in 6-m strips, $12 \mathrm{~m}$ long in four replications, within a randomized strip split-plot design. Seeding dates for the experiment were April 20, 2010, and April 18, 2011, in adjacent areas. Seeding rates of the species and cultivars provided approximately 250,000 seeds $\cdot$ ha $^{-1}$ and are listed in Table 2.

The seeded strips of legumes were randomly split into three 2-m subplots, each with six 25-cm rows, to determine the effects of pesticide protection on establishment. Grass suppression treatments (Table 3) were applied in 4-m strips randomly across each replication perpendicular to pesticide treatments, providing individual subplots of 1.5 by $4 \mathrm{~m}$.

Legume seedling counts were taken randomly within a rectangle $33 \mathrm{~cm}$ long across the two center rows. In 2010, the rectangle was tossed about midway through the plot length; in 2011, two rectangles were counted at about one-third and two-third of the plot length, respectively. Legume seedling counts were made on June 17, 2010, and June 1, 2011, corresponding to 58 and 50 days after planting (DAP), respectively.

Data were analyzed using PROC MIXED in SAS [16], with replication considered random and all other factors fixed. Fisher's protected LSD was used for multiple comparisons $(\alpha=0.05)$.

\subsection{Experiment 2: Grass Suppression by Grazing vs. Chemicals}

The same three legume species (Table 2) were mixed and interseeded as previously described into endophyte- 
Table 1. Monthly 30-year temperature and precipitation averages and departures from average for each location-year.

\begin{tabular}{|c|c|c|c|c|c|c|c|}
\hline \multirow[b]{3}{*}{ Item } & \multirow[b]{3}{*}{ Month } & \multicolumn{3}{|c|}{ Mound valley } & \multicolumn{3}{|c|}{ Parsons } \\
\hline & & \multirow{2}{*}{$\begin{array}{l}\text { 30-year } \\
\text { Average }\end{array}$} & \multicolumn{2}{|c|}{ Departure from average } & \multirow{2}{*}{$\begin{array}{l}\text { 30-year } \\
\text { Average }\end{array}$} & \multicolumn{2}{|c|}{ Departure from average } \\
\hline & & & 2010 & 2011 & & 2012 & 2013 \\
\hline \multicolumn{8}{|c|}{ Temperature, ${ }^{\circ} \mathrm{C}$} \\
\hline & March & 7.7 & -0.4 & 0.6 & 7.8 & 6.1 & -4.4 \\
\hline & April & 13.1 & 2.3 & 0.7 & 13.2 & 2.7 & -3.9 \\
\hline & May & 18.6 & -0.4 & -1.2 & 18.5 & 2.7 & -1.7 \\
\hline & June & 23.5 & 2.0 & 2.7 & 23.4 & 1.0 & 0.6 \\
\hline \multicolumn{8}{|c|}{ Precipitation, mm } \\
\hline & March & 88.1 & -17.0 & 85.1 & 81.0 & 77.2 & -51.3 \\
\hline & April & 109.7 & -70.6 & 19.1 & 111.3 & 122.4 & -19.8 \\
\hline & May & 167.6 & -25.7 & -45.2 & 150.6 & -24.6 & -4.1 \\
\hline & June & 151.9 & 7.1 & -107.7 & 140.5 & -92.5 & -77.7 \\
\hline
\end{tabular}

Table 2. Legumes and rates (pure, live seed) interseeded into endophyte-infected tall fescue in 2010 and 2011, Mound Valley Unit, Southeast Agricultural Research Center.

\begin{tabular}{cccc}
\hline Legume & Species & Cultivar & Seeding rate \\
\hline Red clover & Trifolium pratense & Cinnamon plus & 16.8 \\
Birdsfoot trefoil & Lotus corniculatus & Norcen & 9.0 \\
White (ladino) clover & Trifolium repens & Pinnacle & 4.5 \\
\hline
\end{tabular}

Table 3. Pesticide protection and fescue suppression treatments to enhance legume establishment in endophyte-infected tall fescue in 2010 and 2011, Mound Valley Unit, Southeast Agricultural Research Center.

\begin{tabular}{|c|c|c|c|}
\hline \multirow[b]{2}{*}{ Treatment } & \multirow[b]{2}{*}{ Material } & \multicolumn{2}{|l|}{ Application } \\
\hline & & Date & Rate \\
\hline \multirow{6}{*}{ Pesticide } & & & $\mathrm{kg} \cdot \mathrm{ha}^{-1}$ \\
\hline & Fungicide & & \\
\hline & Mefenoxam-fludioxonil & Seed treatment & \\
\hline & Pyraclostrobin foliar spray & May 21, 2010; May 24, 2011 & 0.16 \\
\hline & Insecticide & & \\
\hline & Thiamethoxam & Seed treatment & \\
\hline \multirow{3}{*}{ Fescue suppression } & Chlorpyrifos foliar spray & May 21, 2010; May 24, 2011 & 0.84 \\
\hline & Glyphosate & April 8, 2010; April 11, 2011 & 0.16 \\
\hline & Clipping & April 9, 29 and May 24, 2010; April 11 and May 17, 2011 & -- \\
\hline
\end{tabular}

infected tall fescue that had been managed as pasture, including fertilization, for $>5$ years at the Parsons Unit of the Southeast Agricultural Research Center ( $\left.37^{\circ} 21.6^{\prime} \mathrm{N}, 95^{\circ} 17.3^{\prime} \mathrm{W}\right)$ on Parsons silt loam. Spring temperature and precipitation data for the location in 2012 and 2013 are listed in Table 1. Plots (9.1 by 3.7 m) were seeded as previously described, in separate experiments on February 27, 2012, and March 15, 2013, with the cultivars and the rates listed (Table 2).

Suppression treatments were 1) grazing in lieu of clipping, 2) chemical suppression, and 3) an untreated check, 
randomized in four blocks. Heifers ( $>225 \mathrm{~kg}$ ) of primarily Angus breeding were excluded from treatments 2 and 3 with electric fence. Grazed plots were stocked intensively in 2012 from April 12 through May 16. In 2013, plots were grazed from April 22 through May 6 and again from May 17 through 28. Chemical suppression was provided with $0.14 \mathrm{~kg} / \mathrm{ha}$ of clethodim on March 30 in 2012 and on April 19 in 2013.

In 2012, legume seedling counts were made on June 6, or 100 DAP, and in 2013, counts were taken on June 21, or 98 DAP. Legume seedling counts were taken randomly within a rectangle $76 \mathrm{~cm}$ long across the two center rows about midway through the plot length.

\section{Results and Discussion}

\subsection{Experiment 1: Pest Control and Grass Suppression}

Early spring moisture at Mound Valley in 2010 was lower than in 2011 and lower than the long-term average (Table 1). However, legume seedling density did not differ at $\geq 50$ DAP between years, and no interaction between year and any treatment factor was detected, so two-year averages are shown. Legume species differed in seedling density, with red clover density greater $(\mathrm{P}<0.05)$ than that of white clover and alfalfa (data not shown). The relative ability of red clover to establish was typical of most experiments (e.g., Guretzky et al. [14]) owing to the larger seed size of the short-term perennial.

There was a significant $(\mathrm{P}<0.01)$ interaction among the three treatments, so means within legume, pest protection, and fescue suppression treatments are shown in Table 4. Red clover seedling density was initially higher than that of the other legumes (data not shown), but by 50 DAP, seedling density of some red clover treatments was no greater than that of a corresponding treatment of birdsfoot trefoil, and even of white clover when both were untreated.

Red clover seedling density was increased by protection with insecticide only when fescue was not suppressed. Grass suppression by glyphosate increased red clover density except where insecticide was used, and suppression by clipping increased density only when no pest protection was provided. The lack of treatment additivity could indicate some interaction between the legume and effects of the pesticide(s). Seedling density of birdsfoot trefoil and white clover seemed unaffected by pest protection or tall fescue suppression. In contrast, Cuomo et al. [12] found that suppression by glyphosate of cool-season grasses enabled much greater success in obtaining legume stands that included alfalfa, birdsfoot trefoil, red clover, and kura clover (Trifolium ambiguum M. Bieb.). Seguin et al. [13] also found that sod suppression by glyphosate or physical methods contributed to higher red, and particularly white, clover densities. The limited responses to suppression in this experiment may

Table 4. Two-year average seedling density of three legumes interseeded into tall fescue as affected by pest protection and fescue suppression.

\begin{tabular}{|c|c|c|c|c|}
\hline \multirow[b]{2}{*}{ Legume } & \multirow[b]{2}{*}{ Pest protection } & \multicolumn{3}{|c|}{ Fescue suppression } \\
\hline & & None & Clip & Glyphosate \\
\hline \multicolumn{5}{|c|}{ Seedlings $\mathrm{m}^{-2}$} \\
\hline \multirow[t]{3}{*}{ Red clover } & None & 114 & 250 & 182 \\
\hline & Fungicide & 163 & 160 & 226 \\
\hline & Insecticide & 190 & 192 & 198 \\
\hline \multirow[t]{3}{*}{ White clover } & None & 124 & 97 & 114 \\
\hline & Fungicide & 114 & 89 & 104 \\
\hline & Insecticide & 81 & 104 & 113 \\
\hline \multirow[t]{4}{*}{ Birdsfoot trefoil } & None & 152 & 137 & 113 \\
\hline & Fungicide & 120 & 172 & 118 \\
\hline & Insecticide & 136 & 170 & 155 \\
\hline & \multicolumn{4}{|c|}{$\mathrm{LSD}_{0.05}=58$} \\
\hline
\end{tabular}


relate to the lack of sufficient $\mathrm{N}$ to invigorate tall fescue growth [14]. An overall reduction in grass competitiveness was necessary at one site for physical grass suppression methods to equal chemical suppression [13]; thus, a recommendation for legume establishment without chemicals might be to reduce or eliminate $\mathrm{N}$ fertility or otherwise diminish the grass' energy reserves in the period prior to interseeding.

\subsection{Grass Suppression by Grazing vs. Chemicals}

The mean responses for legume seedling density to suppression treatments in 2012 and 2013 are shown by species, because legume $\times$ treatment interactions were often significant (Table 5). Year $\times$ treatment interactions were not significant $(\mathrm{P}>0.05)$ for red clover or for birdsfoot trefoil. Red clover seedling densities were not significantly affected by treatment, whereas for birdsfoot trefoil, chemical suppression significantly increased seedling density compared with no treatment (the check) and grazing (Table 5).

White clover seedling density exhibited a year $\times$ treatment interaction (Table 6). This occurred because the few seedlings found in 2012 resulted in no significant treatment difference, but the higher seedling density in 2013 resulted in significant differences. The two-year average seedling density in Table 5 with grass suppression appeared significantly better than the check. Seedling densities for the treatments by year (Table 6) indicate no difference because of largely unsuccessful establishment in 2012. In 2013, however, densities from chemical and grazed treatments were similar, but both were significantly $(\mathrm{P}>0.05)$ greater than the check.

Seedling densities of red clover and birdsfoot trefoil were also much higher at 100 DAP in 2013 than in 2012 (data not shown). Poor legume establishment in 2012 may have been related to the warmer, drier conditions in May and early June compared with those in 2013 and the long-term average (Table 1), emphasizing the role of environmental conditions at critical seedling stages.

\section{Conclusions}

The ability of red clover to establish stands with some grass competition, and with a less favorable environment compared with slower-establishing legumes, was demonstrated in these experiments, although the number ofseedlings that survived in 2012 was less than $20 \%$ of those in 2013. A trend for lower establishment with grazing than chemical suppression could have resulted from treading or grazing damage [13]. This result suggests

Table 5. Average seedling density of three legumes from seedings in 2012 and 2013 as affected by tall fescue suppression by grazing or chemical treatments.

\begin{tabular}{|cccc|}
\hline Suppression method & Red clover & White clover & Birdsfoot trefoil \\
\hline No suppression & \multicolumn{1}{c}{ Seedlings m ${ }^{-2}$} \\
Grazed & 116 & 17 & 22 \\
Chemical & 87 & 46 & 30 \\
LSD $_{0.05}$ & 144 & 40 & 53 \\
\hline
\end{tabular}

${ }^{1}$ Treatment $\times$ year interaction significant $(\mathrm{P}<0.05)$.

Table 6. White clover seedling density in tall fescue from seedings in 2012 and 2013 as affected by tall fescue suppression by grazing and herbicide treatments.

\begin{tabular}{|c|c|c|}
\hline \multirow{2}{*}{$\begin{array}{c}\text { Suppression } \\
\text { Treatment }\end{array}$} & \multicolumn{2}{|c|}{ Year } \\
\hline & 2012 & 2013 \\
\hline & \multicolumn{2}{|c|}{ Seedlings $\mathrm{m}^{-2}$} \\
\hline None & 0 & 34 \\
\hline Grazed & 1 & 93 \\
\hline Chemical & 1 & 77 \\
\hline $\mathrm{LSD}_{0.05}$ & NS & 28 \\
\hline
\end{tabular}


that perhaps grazing should be terminated earlier for red clover than for the other species.

Birdsfoot trefoil establishment benefited more from the immediate, temporary effect of chemical treatment than from the more prolonged effects of grazing. This observation is consistent with observations that the species is most sensitive to grass competition at early seedling stages. The fact that white clover establishment was enabled at least as much by grazing as by chemical treatment may indicate that it benefited from the lengthier period of grass suppression provided by grazing and/or was less subject to grazing or treading damage than the other species.

When comparing species, establishment success should be interpreted differently for different species. Populations that could result in productive stands for grazing vary according to species' growth habits. For example, red clover, a biennial with an upright, bunch-type growth habit, may require a higher population to be acceptable than white clover, a perennial that can vegetatively propagate itself by stolons.

\section{Acknowledgements}

This is contribution no. 15-239-J from the Kansas Agricultural Experiment Station, Manhattan, KS, USA. The research was partially funded by USDA-NIFA Regional Project NC-1181. The technical assistance of C. M. Cramer, K. R. McNickle, and L. D. Sale is appreciated.

\section{References}

[1] Russelle, M. and Birr, A. (2004) Large-Scale Assessment of Symbiotic Dinitrogen Fixation by Crops: Soybean and Alfalfa in the Mississippi River Basin. Agronomy Journal, 96, 1754-1760. http://dx.doi.org/10.2134/agronj2004.1754

[2] Matches, A.G. (1989) A Survey of Legume Production and Persistence in the United States. In: Marten, G.C., et al., Eds., Persistence of Forage Legumes, ASA, CSSA, and SSSA, Madison, 37-45.

[3] Burton, G.W. (1992) Growing Legumes with Coastal Bermudagrass in the Lower Coastal Plains. Journal of Production Agriculture, 5, 278-281. http://dx.doi.org/10.2134/jpa1992.0278

[4] Sheaffer, C.C. (1990) Grass Dominance and Mixture Yield and Quality in Perennial Grass_Alfalfa Mixtures. Journal of Production Agriculture, 3, 480-485. http://dx.doi.org/10.2134/jpa1990.0480

[5] Burns, J.C. and Chamblee, D.S. (1979) Adaptation. In: Buckner, R.C. and Bush, L.P., Eds., Tall Fescue, ASA, CSSA, and SSSA, Madison, 9-30.

[6] Deak, A., Hall, M.H., Sanderson, M.A. and Archibald, D.D. (2007) Production and Nutritive Value of Grazed Simple and Complex Forage Mixtures. Agronomy Journal, 99, 814-821. http://dx.doi.org/10.2134/agronj2006.0166

[7] Rayburn, E.B., Blazer, R.E. and Fontenot, J.P. (1980) In Vivo Quality of Tall Fescue as Influenced by Season, Legumes, Age, and Canopy Strata. Agronomy Journal, 72, 872-876. http://dx.doi.org/10.2134/agronj1980.00021962007200060004x

[8] Burton, R.O., Berends, P.T., Moyer, J.L., Coffey, K.P. and Lomas, L.W. (1994) Economic Analysis of Grazing and Subsequent Feeding of Steers from Three Fescue Pasture Alternatives. Journal of Production Agriculture, 7, 482-489. http://dx.doi.org/10.2134/jpa1994.0482

[9] Moyer, J.L., Dhuyvetter, K.C. and Shoup, D. (2009) Comparison of Returns from Legumes in Endophyte-Infected Tall Fescue for Hay. Forage and Grazinglands, 7, 1. http://dx.doi.org/10.1094/FG-2009-1014-01-RS

[10] Allen, V.G., Fontenot, J.P. and Notter, D.R. (1992) Forage Systems for Beef Production from Conception to Slaughter: II. Stocker Systems. Journal of Animal Science, 70, 588-596.

[11] Lomas, L.W., Moyer, J.L. and Kilgore, G.L. (1999) Effect of Interseeding Legumes into Endophyte-Infected Tall Fescue Pastures on Forage Production and Steer Performance. Journal of Production Agriculture, 12, 479-483. http://dx.doi.org/10.2134/jpa1999.0479

[12] Cuomo, G.J., Johnson, D.G. and Head, W.A. (2001) Interseeding Kura Clover and Birdsfoot Trefoil into Existing Cool-Season Grass Pastures. Agronomy Journal, 93, 458-462. http://dx.doi.org/10.2134/agronj2001.932458x

[13] Seguin, P., Peterson, P.R., Sheaffer, C.C. and Smith, D.L. (2001) Physical Sod Suppression as an Alternative to Herbicide Use in Pasture Renovation with Clovers. Canadian Journal of Plant Science, 81, 255-263. http://dx.doi.org/10.4141/P00-023

[14] Guretzky, J.A., Moore, K.J., Knapp, A.D. and Brummer, E.C. (2004) Emergence and Survival of Legumes Seeded into Pastures Varying in Landscape Position. Crop Science, 44, 227-233. http://dx.doi.org/10.2135/cropsci2004.0227

[15] Butler, T.J., Stein, J.D., Interrante, S.M. and Malinowski, D.P. (2011) Novel Approaches to Establishing Alfalfa-Tall Fescue Pastures in the Southern Great Plains. Forage and Grazinglands, 9, 1. 
http://dx.doi.org/10.1094/FG-2011-0725-01-RS

[16] Littell, R.C., Milliken, G.A., Stroup, W.W. and Wolfinger, R.D. (1996) SAS System for Mixed Models. SAS Institute, Inc., Cary, NC, USA. 
Scientific Research Publishing (SCIRP) is one of the largest Open Access journal publishers. It is currently publishing more than 200 open access, online, peer-reviewed journals covering a wide range of academic disciplines. SCIRP serves the worldwide academic communities and contributes to the progress and application of science with its publication.

Other selected journals from SCIRP are listed as below. Submit your manuscript to us via either submit@scirp.org or Online Submission Portal.
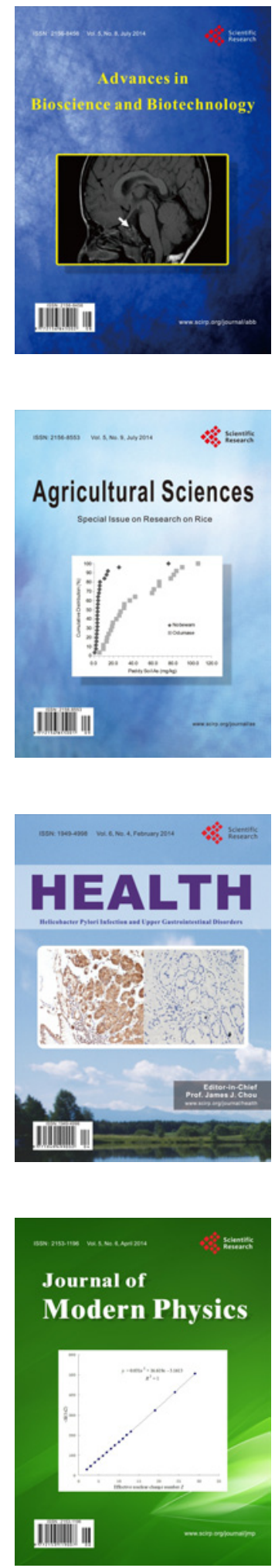
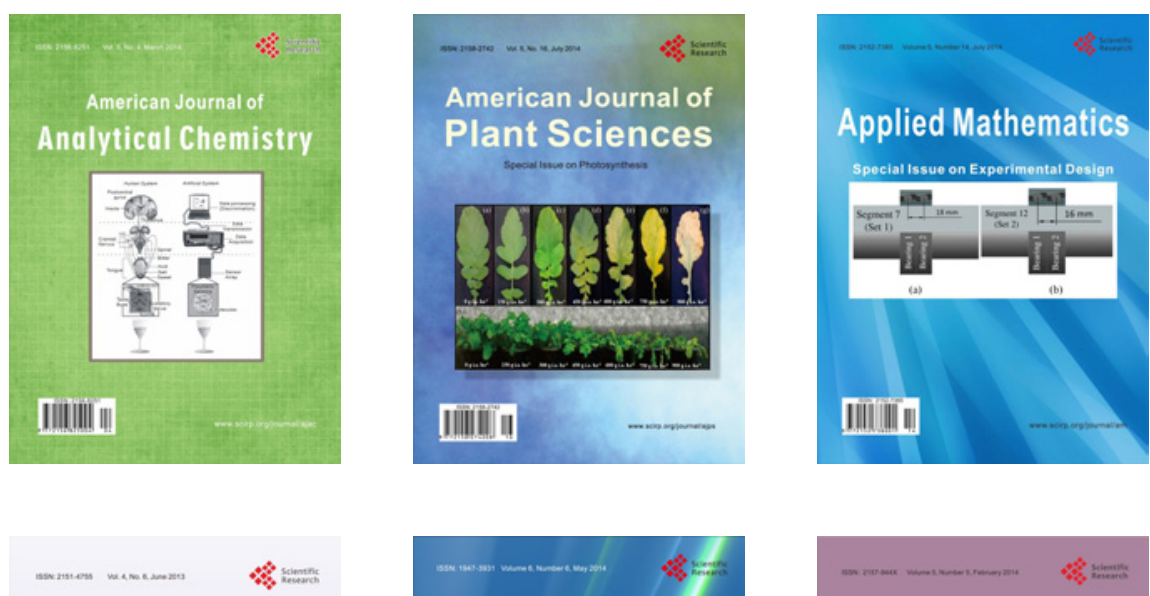

Creative Education
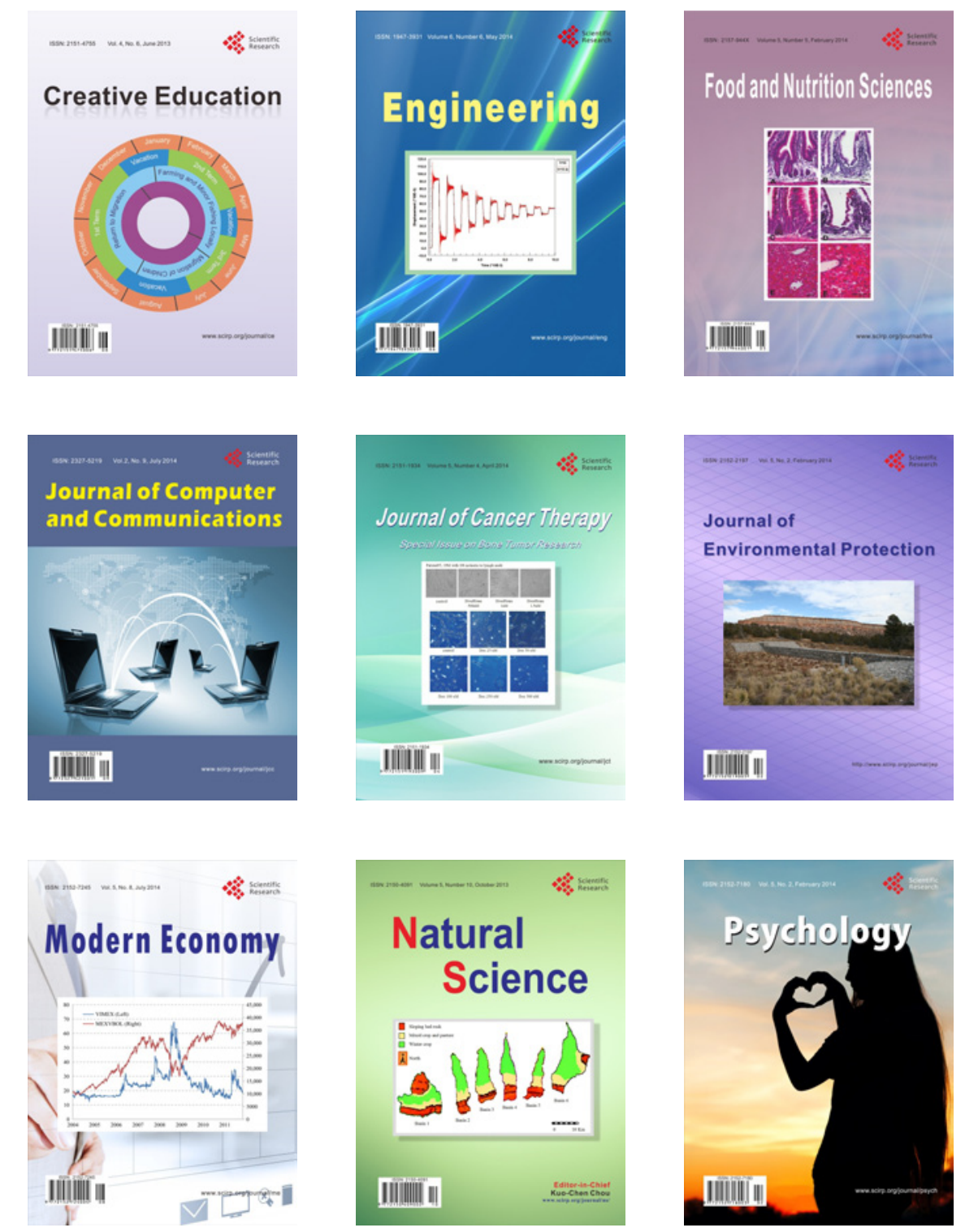